University of Nebraska - Lincoln

DigitalCommons@University of Nebraska - Lincoln

Faculty Publications: Department of

Entomology

Entomology, Department of

2000

\title{
Differentiation of Three Phenotypically Similar Blattella spp.: Analysis with Polymerase Chain Reaction-Restriction Fragment Length Polymorphism of Mitochondrial DNA
}

\author{
Pari Pachamuthu \\ University of Nebraska-Lincoln \\ Shripat T. Kamble \\ Universitiy of Nebraska--Lincoln, skamble1@unl.edu \\ Thomas L. Clark \\ University of Nebraska-Lincoln \\ John E. Foster \\ University of Nebraska-Lincoln, john.foster@unl.edu
}

Follow this and additional works at: https://digitalcommons.unl.edu/entomologyfacpub

Part of the Entomology Commons

Pachamuthu, Pari; Kamble, Shripat T.; Clark, Thomas L.; and Foster, John E., "Differentiation of Three Phenotypically Similar Blattella spp.: Analysis with Polymerase Chain Reaction-Restriction Fragment Length Polymorphism of Mitochondrial DNA" (2000). Faculty Publications: Department of Entomology. 304.

https://digitalcommons.unl.edu/entomologyfacpub/304

This Article is brought to you for free and open access by the Entomology, Department of at DigitalCommons@University of Nebraska - Lincoln. It has been accepted for inclusion in Faculty Publications: Department of Entomology by an authorized administrator of DigitalCommons@University of Nebraska - Lincoln. 


\title{
Differentiation of Three Phenotypically Similar Blattella spp.: Analysis with Polymerase Chain Reaction-Restriction Fragment Length Polymorphism of Mitochondrial DNA
}

\author{
PARI PACHAMUTHU, SHRIPAT T. KAMBLE ${ }^{1}$, THOMAS L. CLARK, AND JOHN E. FOSTER \\ Department of Entomology, University of Nebraska, NE 68583-0816
}

\begin{abstract}
Ann. Entomol. Soc. Am. 93(5): 1138-1146 (2000)
ABSTRACT Differentiation of Blattella asahinai Mizukubo, Blattella vaga Hebard, and Blattella germanica (L.) was investigated using polymerase chain reaction-restriction fragment length polymorphism (PCR-RFLP). DNA fragments corresponding to mitochondrial CO1, CO1/TL2 (small and large fragments), and ITS2 regions were amplified using PCR. The universal primers used for amplifying mitochondrial CO1 and CO1/TL2 (small and large fragments) were CO1-J-1718/CO1N-2191, CO1-J-2441/TL2-N-3014, and CO1-J-1751/TL2-N-3014. Amplification was observed with all primer combinations, but diagnostic patterns were found only with AluI digested amplicons of CO1 and CO1/TL2 (large fragments) regions. Both inter/intraspecific polymorphism was observed for the 517 bp CO1 region between German (A, B) and Asian (A, B, C) cockroach populations. Polymorphic form B of the Asian cockroach (374 and $179 \mathrm{bp}$ fragments) was nearly identical to the field cockroach (370 and $178 \mathrm{bp}$ fragments). The CO1 amplicon (517 bp) differentiated German and field cockroaches but not Asian and field cockroaches. The CO1/TL2 amplicons (1275 bp) digested with $A l u \mathrm{I}$ clearly differentiated all three species. The Asian cockroach had a distinct $540 \mathrm{bp}$ fragment, whereas the field cockroach had a $403 \mathrm{bp}$ fragment and the German cockroach lacked both fragments. Intraspecific polymorphs for CO1/TL2 amplicons (1275 bp) were observed with the German cockroach only. Portions of the CO1 and TL2 genes were sequenced, revealing 76\% identity among German, Asian, and field cockroaches. Sequence data also revealed that German and Asian cockroaches were more closely related to each other than to the field cockroach.
\end{abstract}

KEY WORDS Blattella asahinai, Blattella germanica, Blattella vaga, polymerase chain reactionrestriction fragment length polymorphism, mitochondrial DNA

IN NORTH AMERICA, three morphologically similar Blattella spp., namely the Asian cockroach, B. asahinai Mizukubo, the field cockroach, B. vaga Hebard, and the German cockroach, B. germanica (L.), are known to occur. They can be easily misidentified (Benson and Zungoli 1997). Flock (1941) reported morphological similarities between German and field cockroaches, and Roth (1986) and Hall (1987) noted that Asian and German cockroaches are difficult to differentiate from each other. Currently, morphological characters, such as size and shape of tergal glands (Roth 1986, Appel 1995 ) and the genital hook of males, are used to differentiate Asian, German, and field cockroaches (Atkinson et al. 1991, Appel 1995). Ross and Mullins (1988) differentiated first instars, large nymphs, and oothecae of German and Asian cockroaches using size and color patterns. Lawless (1999) described five additional characters (setae on mandibles, coloration of right tegmen, number of veins in the hind wing and size and shape of marginal bristles on cerci) to differentiate Asian and German cockroach. A major limitation for the use of morphological characters is the required expertise of a trained entomologist (Appel

\footnotetext{
${ }^{1}$ To whom reprint request should be addressed.
}

1995, Lawless 1999). Moreover, the use of morphological characters for species identification causes difficulty when damaged specimens are used, a situation commonly encountered by pest control professionals.

Behavioral keys based on flight and response to light is another approach to differentiate German, Asian, and field cockroaches (Appel 1995). Generally, Asian cockroaches are strong fliers and are attracted to light (Benson and Zungoli 1997). These characters have led to the establishment of the Asian cockroach population in an area $900 \mathrm{~km}$ inland from Tampa, FL, the probable point of its entry into the United States (Roth 1986, Brenner et al. 1988). Thus, the spread of Asian cockroaches into areas already infested with the German cockroach creates identification and control problems for pest control professionals (Hall 1987). This is further complicated by the observation of Asian and German cockroaches inside homes (Brenner et al. 1988). No insecticide resistance in Asian cockroaches has been reported, whereas German cockroaches have developed resistance to various classes of insecticides (Hall 1987). German and Asian cockroaches can interbreed and produce viable offspring, which can make identification of hybrids extremely difficult and also increases the concern for resistance devel- 
Table 1. Primer combinations used in the amplification of 4 DNA fragments in Asian, field, and German cockroaches

\begin{tabular}{|c|c|c|c|}
\hline $\begin{array}{l}\text { Forward } \\
\text { Primer }\end{array}$ & Sequence $5^{\prime}-3^{\prime}$ & $\begin{array}{l}\text { Reverse } \\
\text { Primer }\end{array}$ & Sequence $5^{\prime}-3^{\prime}$ \\
\hline Cl-J-1718 & $\begin{array}{l}\text { GGAGGATTTGGAAATTGATT } \\
\text { AGTTCC }\end{array}$ & $\mathrm{C} 1-\mathrm{N}-2191^{a}$ & $\begin{array}{c}\text { CCCGGTAAAATTAAAATATAA } \\
\text { ACTTC }\end{array}$ \\
\hline CI-J-2441 ${ }^{a}$ & $\begin{array}{l}\text { CCAACAGGAATTAAAATTTT } \\
\text { TAGATGATTAGC }\end{array}$ & TL2-N-3014 $4^{a}$ & $\begin{array}{c}\text { TCCAATGCACTAATCTGCCATA } \\
\text { TTA }\end{array}$ \\
\hline $\mathrm{C} 1-\mathrm{J}-1751^{a}$ & $\begin{array}{l}\text { GGATCACCTGATATAGCATT } \\
\text { CCC }\end{array}$ & TL2-N-3014 $4^{a}$ & $\begin{array}{c}\text { TCCAATGCACTAATCTGCCATA } \\
\text { TTA }\end{array}$ \\
\hline ITS $^{b}$ & ATATGCTTAAATTCAGCGGG & ITS $2^{b}$ & GGGTCGATGAAGAACGCAGC \\
\hline
\end{tabular}

${ }^{a}$ Simon et al. (1994).

${ }^{b}$ Navajas et al. (1998).

opment in the Asian cockroach (Roth 1986, Ross 1992).

A third approach for differentiating cockroach species is cuticular hydrocarbon analysis (Carlson and Brenner 1988). These authors used the technique to differentiate Asian, field, and German cockroaches from one another and observed significant differences in hydrocarbon component patterns among males, females, and nymphs. Although analysis of cuticular hydrocarbons is useful for species discrimination, they vary in composition based on sex, age, population origin, environmental condition, and physiological state of a species (Hadley 1977, Blomquist et al. 1987, Carlson and Brenner 1988, Toolson et al. 1990, Golden et al. 1992).

Use of the PCR has revolutionized the field of molecular biology, and it is now possible to differentiate species using small amounts of DNA (Simon et al. 1994). Both nuclear and mitochondrial genes have proven to be useful for molecular diagnostics (Moritz et al. 1987, Kirby 1990). PCR-RFLP has been used for species discrimination of Aedes spp. (West et al. 1997) and Anopheles spp. (Beebe and Saul 1995) mosquitoes, whereas direct RFLP of mitochondrial DNA has been used for species discrimination of termites (Broughton 1995). Further, PCR amplified products were used for direct sequencing of previously unknown regions. Kambhampati $(1995,1996)$ used PCR products of mitochondrial ribosomal genes for sequence determination and to examine the phylogenetic relationship of cockroaches, termites and mantids.

The primary objectives of our research were to differentiate B. asahinai, B. germanica, and B. vaga based on mitochondrial DNA using PCR-RFLP analysis; and to sequence the amplified fragments of cytochrome oxidase 1 (CO1)/tRNA-Leucine (TL2) gene. DNA sequencing was performed to determine the base sequence of the amplified fragment and to construct a dentogram based on the sequence identity.

\section{Materials and Methods}

Test Insects and DNA Isolation. Adult males from three laboratory-cultured colonies of $B$. germanica, $B$. asahinai, and B. vaga were used. B. germanica $(n=15)$ was a laboratory colony from Lincoln, $\mathrm{NE}$, and $B$. asahinai $(n=15)$ and B. vaga $(n=7)$ were laboratory colonies from Auburn, AL. Voucher specimens are maintained at the Department of Entomology, University of Nebraska, Lincoln, NE.

The insects were frozen at $-20^{\circ} \mathrm{C}$ for $2 \mathrm{~d}$ before DNA extraction. DNA was isolated from the thorax using a phenol-chloroform extraction method (Maniatis et al. 1982), as modified by Taylor et al. (1996). The extraction process included homogenizing a thorax in $200 \mu \mathrm{l}$ of lysis buffer $(100 \mathrm{mM} \mathrm{NaCl}, 100 \mathrm{mM}$ EDTA, $100 \mathrm{mM}$ of Tris, $0.5 \%$ SDS, pH 7.0) followed by incubation steps after addition of proteinase $\mathrm{K}(4 \mu \mathrm{l}$ of $20 \mathrm{mg} / \mathrm{ml})$ at $55^{\circ} \mathrm{C}$ for $3 \mathrm{~h}$ followed by RNAase $(2 \mu \mathrm{l}$ of $10 \mathrm{mg} / \mathrm{ml}$ ) at $37^{\circ} \mathrm{C}$ for $20 \mathrm{~min}$. DNA pellets were precipitated in $100 \%$ ethanol and stored overnight at $-20^{\circ} \mathrm{C}$. Finally, the DNA was washed in $70 \%$ ethanol, centrifuged, and vacuum dried. DNA was then resuspended in $100 \mu \mathrm{l}$ of TE buffer ( $10 \mathrm{mM}$ Tris, $\mathrm{pH} 8.0$ and one mM EDTA) and stored at $-20^{\circ} \mathrm{C}$.

PCR Amplification. PCR amplification was done with a programmable thermal controller (PTC-100) (MJ Research, Waltham, MA); and a total of four mitochondrial and nuclear genes were amplified. We did not separate the mitochondrial and nuclear DNA. Instead the primers used in the amplification process are designed either to amplify the insect mtDNA (Simon et al. 1994) or nuclear rDNA (Navajas et al. 1998). The three amplified regions were as follows: (1) a central portion of the mitochondrial CO1 gene amplified using the primers C1-J-1718 and C1-N-2191; (2) two (large and small) portions of mitochondrial CO1 and an adjoining portion of the tRNA-Leucine (TL2) gene amplified using the primers Cl-J-1751 and TL2-N-3014, and CI-J-2441 and TL-2-N-3014, respectively; and (3) the nuclear ribosomal ITS2 region amplified using the primers listed by Navajas et al. (1998). The primer sequences are presented in Table 1. Composition of the reaction mixture $(50 \mu \mathrm{l})$ used for amplification with the primers, C1-J-1718, C1-N-2191, CI-J-2441, and TL-2-N-3014 was $28.5 \mu \mathrm{l}$ water, $5 \mu \mathrm{l} 10 \times$ PCR buffer II (PE Applied Biosystems, Branchburg, $\mathrm{NJ}), 800 \mu \mathrm{M}$ dNTP mix (PE Applied Biosystems), 0.8 $\mu \mathrm{M}$ of each primer, $2.5 \mathrm{U}$ AmpliTaq DNA polymerase (PE Applied Biosystems), $2 \mu \mathrm{l} \mathrm{DNA}$, and $3 \mathrm{mM} \mathrm{MgCl}_{2}$. Amplification was performed using the following temperature profile: $94^{\circ} \mathrm{C}$ for $2 \mathrm{~min}, 35$ cycles of $94^{\circ} \mathrm{C}$ for $45 \mathrm{~s}, 48^{\circ} \mathrm{C}$ for $1 \mathrm{~min}$, and $72^{\circ} \mathrm{C}$ for $1.5 \mathrm{~min}$. After a final extension step at $72^{\circ} \mathrm{C}$ for $5 \mathrm{~min}$, PCR products were stored at $4^{\circ} \mathrm{C}$. 
Composition of the reaction mixture $(50 \mu \mathrm{l})$ used for amplification of the primers C1-J-1751 and TL-2$\mathrm{N}-3014$ was $21.5 \mu$ l water, $5 \mu \mathrm{l} 10 \times$ PCR buffer II, 1,200 $\mu \mathrm{M}$ dNTP mix, $0.8 \mu \mathrm{M}$ of each primer, $2.5 \mathrm{U}$ AmpliTaq DNA polymerase, $6 \mu$ l DNA template, and $3.5 \mathrm{mM}$ $\mathrm{MgCl}_{2}$. Amplification was done using the following profile: $94^{\circ} \mathrm{C}$ for $2 \mathrm{~min}, 40$ cycles of $94^{\circ} \mathrm{C}$ for $1 \mathrm{~min}, 52^{\circ} \mathrm{C}$ for $30 \mathrm{~s}$, and $72^{\circ} \mathrm{C}$ for $1.5 \mathrm{~min}$. After a final extension step at $72^{\circ} \mathrm{C}$ for $8 \mathrm{~min}$, PCR products were stored at $4^{\circ} \mathrm{C}$.

The reaction mixture $(25 \mu \mathrm{l})$ used for amplification of ITS2 primers was as follows: $12.75 \mu \mathrm{l}$ water, $2.5 \mu \mathrm{l}$ $10 \times$ PCR buffer II, $800 \mu \mathrm{M}$ dNTP mix, $0.8 \mu \mathrm{M}$ of each primer, $2.5 \mathrm{U}$ AmpliTaq DNA polymerase, $3 \mu \mathrm{l}$ DNA template, and $2.5 \mathrm{mM} \mathrm{MgCl}$. Amplification was done using the following profile: $94^{\circ} \mathrm{C}$ for $5 \mathrm{~min}, 35$ cycles of $94^{\circ} \mathrm{C}$ for $1 \mathrm{~min}, 57^{\circ} \mathrm{C}$ for $30 \mathrm{~s}$, and $72^{\circ} \mathrm{C}$ for $1.5 \mathrm{~min}$. After a final extension step at $72^{\circ} \mathrm{C}$ for $7 \mathrm{~min}$, PCR products were stored at $4^{\circ} \mathrm{C}$. A negative control containing no DNA template was used for each amplification cycle.

Restriction Digestion. After amplification, samples were stored at $4^{\circ} \mathrm{C}$ until they were ready for digestion with restriction enzymes. For restriction digestion, the amplified samples were used directly with restriction enzymes and buffers. Four restriction enzymes, $M f e 1$, MseI, AluI, and MspI, were used for the screening procedure. Restriction digestion with enzymes AluI, Mse I, and MspI was conducted using $1 \times$ Buffer $2(50$ $\mathrm{mM} \mathrm{NaCl}, 10 \mathrm{mM}$ Tris-HCl [pH 7.9], and $1 \mathrm{mM}$ DDT [New England Biolabs, Beverely, MA,]), whereas $1 \times$ Buffer 4 (50 mM potassium acetate, $20 \mathrm{mM}$ Tris acetate, $10 \mathrm{mM}$ magnesium acetate, $1 \mathrm{mM}$ DDT, pH 7.9 [New England Biolabs]) was used for Mfel. The reaction mixtures $(20 \mu \mathrm{l})$ used for various restriction enzyme digestions were as follows: $M f e 1$ digestion- 4 units enzyme, $2.0 \mu \mathrm{l} 1 \times$ Buffer 4 , and $8.0 \mu \mathrm{l}$ DNA template; MseI digestion-4 units enzyme, $2.0 \mu \mathrm{l} 1 \times$ Buffer 2, $0.2 \mu \mathrm{l} \mathrm{BSA}$, and $8.0 \mu$ l DNA template; $M s p \mathrm{I}$ digestion-4 units enzyme, $2.0 \mu \mathrm{l} 1 \times$ Buffer 2 , and 8.0 $\mu \mathrm{l}$ DNA template; and AluI digestion-10 units enzyme, $2 \mu \mathrm{l} 1 \times$ Buffer 2 , and $9.3 \mu \mathrm{l}$ DNA template. Digestion was conducted at $37^{\circ} \mathrm{C}$ for $16 \mathrm{~h}$ using a Perkin Elmer Cetus model 9600 thermocycler (Perkin Elmer, Branchburg, NJ) and the digested products were stored at $4^{\circ} \mathrm{C}$ until fractionation.

Electrophoresis. PCR amplification was confirmed by loading the PCR product onto a $1.0 \%$ agarose TBE (0.089 M Tris, 0.089 M boric acid, 0.5 M EDTA [pH $8.0])$ gel containing ethidium bromide $(0.6 \mathrm{mg} / \mathrm{ml})$. Samples were electrophoresed at $80 \mathrm{~V}$ for $20 \mathrm{~min}$ and visualized using a UV illuminator. Restriction digests were separated on $9 \%$ polyacrylamide gel (PAGE) in a gel unit ( 16 by $20 \mathrm{~cm}$ by $1.5 \mathrm{~mm}$ ) at $200 \mathrm{~V}$ for $4.5 \mathrm{~h}$. After electrophoresis, restriction digestions were visualized with silver staining (Amersham Pharmacology Biotech, Piscataway, NJ) and scanned into a gel documentation program (Genomic Solutions, Ann Arbor, MI).

DNA Sequencing. PCR amplicons for all three species were amplified using the procedure described earlier and purified by Gene Clean II Spin Kit (Bio 101, La Jolla, CA) using the manufacture protocol. The cleaned amplicons were sequenced directly using a LI-COR model 4000 DNA Sequencer (LI-COR, Lincoln, NE) at the DNA Sequencing Core Facility, University of Nebraska, Lincoln, NE. The sequences were aligned using PILEUP (Genetics Computer Group [GCG], Madison, WI). The final sequence reported here was determined by comparing the strands produced by both primers with each other, and the consensus sequences were compared with the sequence from the same regions of other known insect species. Further, this research was not focused on phylogenetic analysis of cockroach species. To illustrate similarity, Jukes-Cantor distances were calculated using the unweighted pair group method of arithmetic averages algorithm, with the resulting matrix data used to draw a similarity tree in the Growtree program (GCG).

\section{Results}

Amplification of mtDNA was observed with all primers in the initial screening of German and Asian cockroaches. For German and Asian cockroaches, the sizes of the amplified products were $517 \mathrm{bp}$ for C1-J1718/C1-N-2191 (Fig. 1), 550 bp for C1-J-2441/TL2$\mathrm{N}-3014$, and $579 \mathrm{bp}$ for the ITS2 region. AluI digestion of 517 bp CO1 amplicons showed both inter/intraspecific polymorphisms between German and Asian cockroaches. Two intraspecific polymorphs were observed for the German, and three polymorphs were observed for the Asian cockroaches. The same $517 \mathrm{bp}$ CO1 amplicon digested with $M s p I$ and $M s e I$ showed no intra- or interspecific polymorphs. Similarly, the 550 bp CO1/TL2 amplicon of German and Asian cockroaches showed no intra- or interspecific polymorphs when digested with $A l u \mathrm{I}, M s p \mathrm{I}$, and $M s e \mathrm{I}$. Two polymorphs were observed for Asian cockroaches with AluI, MspI, and MseI digests of ITS2 amplicon; however, one of the polymorphs of Asian cockroaches was identical to the polymorphs observed in German cockroaches. Mfe 1 digest of ITS2 amplicons also showed no intra- or interspecific polymorphs between German and Asian cockroach.

Subsequently, the $517 \mathrm{bp} \mathrm{CO} 1$ amplicon of German, Asian and field cockroaches was digested with AluI. Diagnostic interspecific polymorphism was observed with the German cockroach but there was no diagnostic interspecific polymorphism for Asian and field cockroaches. The band patterns observed for the German cockroach were clearly distinct from those of the Asian and field cockroach. Fragment sizes for all three species, including the polymorphic forms, based on the migration in polyacrylamide gel are presented in Table 2. Four of 15 German cockroaches showed polymorphic form A, whereas 11 specimens had polymorphic form B (Fig. 2). In the Asian cockroach, polymorphism A was observed only in one individual, and polymorphism B was seen in four individuals, and polymorphism $\mathrm{C}$ in 10 individuals. The polymorphic form B of the Asian cockroach closely resembles that of field cockroach with $4 \mathrm{bp}$ separating the top band and $1 \mathrm{bp}$ separating the bottom band. The fragment 


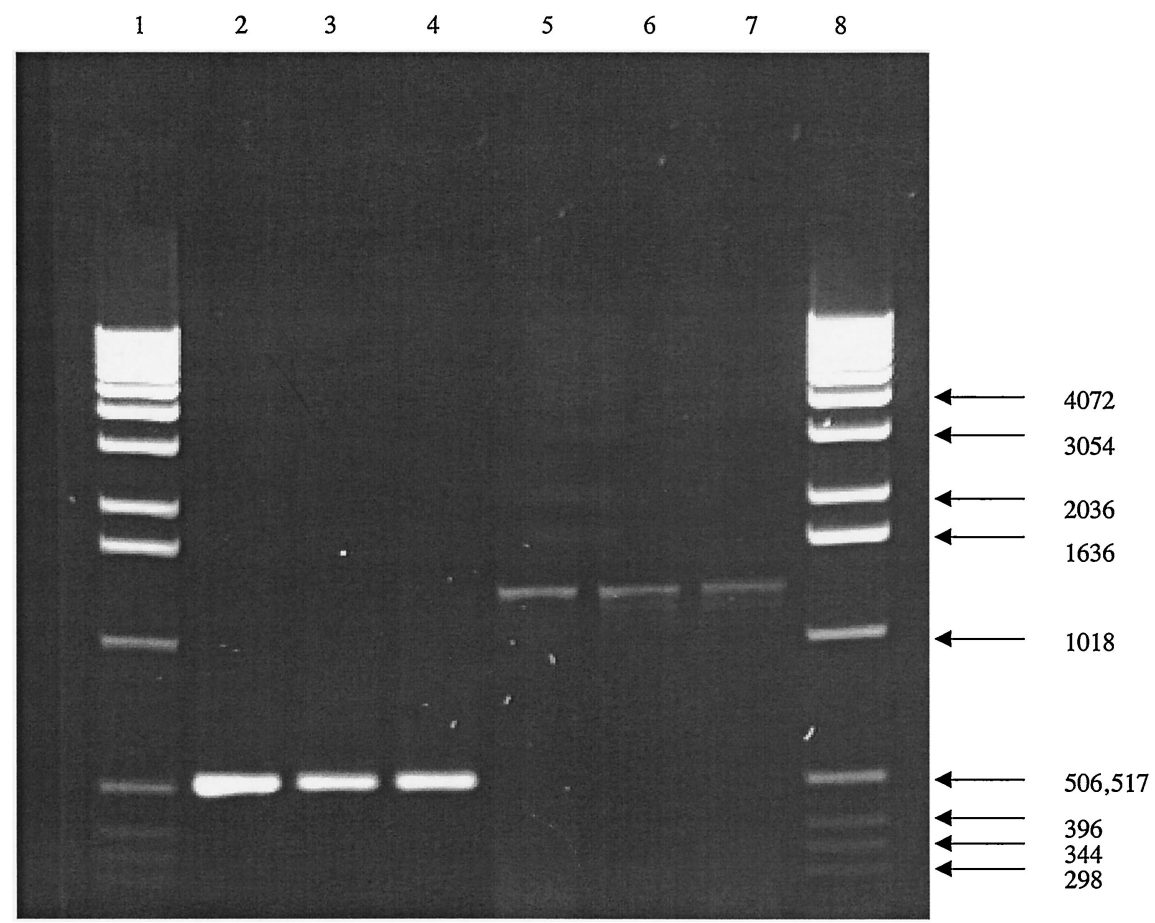

Fig. 1. Undigested amplicons visualized on 1\% Agarose gel stained with ethidium bromide. Lanes 1 and 8: $1 \mathrm{~kb}$ markers. Lane 2: B. germanica (517 bp). Lane 3: B. asahinai (517 bp). Lane 4: B. vaga (517 bp). Lane 5: B. germanica (1275 bp). Lane 6: B. asahinai (1275 bp). Lane 7: B. vaga (1275 bp).

sizes were determined using the gel documentation program and overall eight gels were analyzed.

The 1275 bp CO1/TL2 amplicon (Fig. 1) digested with $A l u \mathrm{I}$ had distinct migration patterns that clearly differentiated all three Blattella species. Two intraspecific polymorphs (A and B) were observed with German cockroach (Fig. 2). Polymorph A was observed in four individuals, whereas polymorph B was observed in 11 individuals. No intraspecific polymorphism was observed with AluI digests of the CO1/TL2 amplicon in both the Asian and field cockroach. Inter- and intra-specific fragment sizes for Asian, field and German cockroach are presented in Table 2.

Table 2. Primers, species and polymorphs identified by fragment size for the German, Asian and field cockroach using $517 \mathrm{bp}$ and 1275 bp amplicons digested by restriction enzyme Alul

\begin{tabular}{lll}
\hline \multicolumn{1}{c}{ Primers combinations } & Species-polymorphs & Fragment sizes, bp \\
\hline Cl-J-1718 and C1-N-2191 & Blattella germanica-A & 344,126 \\
Cl-J-1718 and C1-N-2191 & Blattella germanica-B & 318,125 \\
C1-J-1718 and C1-N-2191 & Blattella asahinai-A & $374,321,^{b} 180$ \\
Cl-J-1718 and C1-N-2191 & Blattella asahinai-B & 374,179 \\
Cl-J-1718 and C1-N-2191 & Blattella asahinai-C & 315,152 \\
Cl-J-1718 and C1-N-2191 & Blattella vaga & 370,178 \\
Cl-J-1751 and TL-2-N-3014 & Blattella germanica-A & $462,381^{a}$ \\
Cl-J-1751 and TL-2-N-3014 & Blattella germanica-B & $471,397,374,118^{b}$ \\
Cl-J-1751 and TL-2-N-3014 & Blattella asahinai & $540,374^{a}$ \\
Cl-J-1751 and TL-2-N-3014 & Blattella vaga & $481,403,377,236^{b}$ \\
\hline
\end{tabular}

${ }^{a}$ Interpreted as double band.

${ }^{b}$ Faint band detected due to silver staining or partial digestion.
The alignment of the CO1/TL2 sequence for all three species is depicted in Fig. 3. There are 23 bases in the field cockroach and 64 bases in the Asian cockroach that lie before the sequences listed in Fig. 3. Our sequence information is available through the

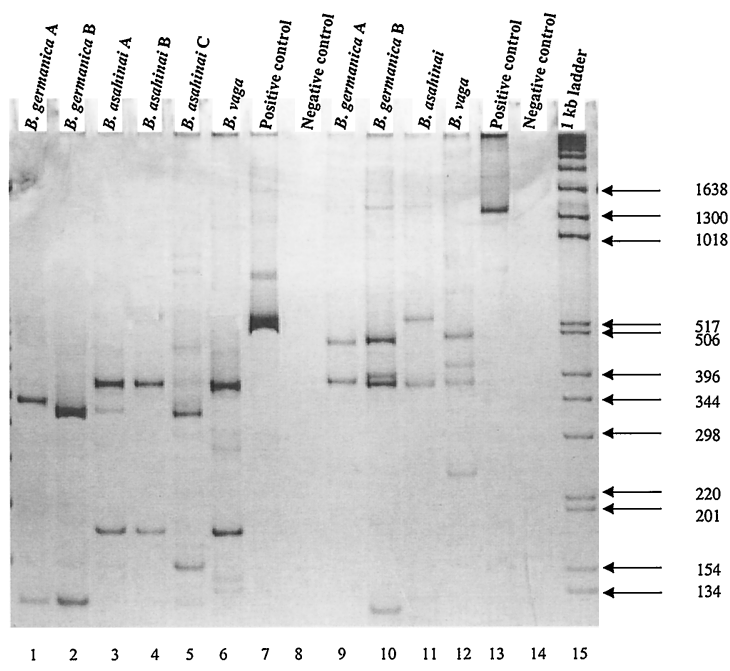

Fig. 2. Alu digests of Blattella spp. on 9\% PAGE. Lanes 1-7: 517 bp CO1 amplicons. Lanes 9-13: 1275 bp CO1/TL2 amplicons. Lanes 8 and 14: negative control. Lane 15: $1 \mathrm{~kb}$ marker. 


\begin{tabular}{|c|c|c|c|c|c|c|c|}
\hline 1 & TAAATAATAT & AAGTTTTTGA & СТTTTACCTC & \multicolumn{2}{|c|}{ САТСТСТАТС } & \multicolumn{2}{|c|}{ TCTTCTATTA } \\
\hline 1 & $\ldots \ldots \ldots$ & $\ldots \ldots c \ldots$ & $\ldots A \ldots A$ & \multicolumn{2}{|c|}{. Т. АT... } & \multicolumn{2}{|c|}{ A...T...G } \\
\hline 1 & $\ldots \ldots \ldots$ & $\ldots \ldots C \ldots$ & $\ldots$ A. . A & \multicolumn{2}{|c|}{. T. AT ... } & \multicolumn{2}{|c|}{ A...T...G } \\
\hline 1 & GCTAGTAGCC & TTGTTGAAAG & AGGAGCTGGG & \multicolumn{2}{|c|}{ ACTGGTTGAA } & \multicolumn{2}{|c|}{ CCGTATACCC } \\
\hline 5 & $\ldots \ldots \mathrm{T}$ & \multirow{2}{*}{$G \cdots \cdots$} & $\ldots$. . . . & \multicolumn{2}{|c|}{$\ldots$ A...... } & \multicolumn{2}{|c|}{. T...T. } \\
\hline 51 & $\ldots \ldots \mathrm{T}$ & & $\ldots$ A.... & \multicolumn{2}{|c|}{$\ldots T \ldots \ldots$} & \multicolumn{2}{|c|}{.C.... } \\
\hline 01 & TCCCTTAGCT & AGAGGAATTG & CTCATGCTGG & $\mathrm{AGC}$ & TTCAGTA & GATTT & AGCTA \\
\hline 101 & A. . TC.... & $\ldots . . .$. & $\ldots \ldots$ & T. . & $A \ldots . T$ & $\cdots \cdots$ & $\ldots A$ \\
\hline 101 & Т..СТ ... & $\ldots$.... & $\ldots \ldots \ldots$ & A.. & $T \ldots A$ & $\ldots \ldots$ & $\ldots \mathrm{T}$ \\
\hline 51 & TTTTCTCATT & ACATCTTGCA & GGTGTCTCAT & CAA' & TTTTAGG & TGCCG & TAAAT \\
\hline 51 & $\ldots$... . & ... . . . & .А. . . . & $\cdots$ & $\ldots \ldots$ & $\ldots \mathrm{T}$. & T... \\
\hline 51 & $\ldots$. .A. & $\ldots$. . T. & . T. . . . & $\cdots$ & $\cdots \cdots$ & $\ldots C$. & A... \\
\hline 01 & TTTATTTCAA & СААТТАТТАА & CATGAAACCA & $\mathrm{ATT2}$ & AATATAA & GACCT & GAACG \\
\hline 201 & $\ldots \ldots \ldots$ & $\ldots \ldots \ldots$ & T. . A . . . T & $\cdots$ & $\ldots \subset \ldots$ & AA. . & $\cdots \cdots$ \\
\hline 201 & $\cdots \cdots \cdots$ & $\ldots \ldots \ldots$ & C..G...A & $\cdots$ & $\ldots$ T. & GC... & $\cdots \cdots$ \\
\hline 51 & АATTCСTTTA & TTTGTTTGGT & CAGTAGGTAT & TAC & TGCATTA & TTATT & ATTAT \\
\hline 251 & $\mathrm{G} \ldots \mathrm{CC} \cdot \mathrm{T}$ & $\ldots$. A. A. & T..... & $\ldots 1$ & A..T... & $\ldots C$. & I. . . \\
\hline 251 & A....TT.A & $\ldots . T \ldots G$ & A...... & $\cdots$ & T.A... & $\ldots \mathrm{T}$. & A.... \\
\hline 301 & TATCCTTACC & AGTTCTTGCA & GGTGCAATTA & CAA? & TATTATT & AACAG & $\mathrm{ACCGA}$ \\
\hline 301 & $\ldots$.... & T..AT.A... & $\ldots$ G. T... & $\cdots$ & $\ldots \ldots$ & $\ldots \mathrm{T}$. &.$T \ldots T$ \\
\hline 301 & $\ldots$. . . . & A..TC.Т... & . T..... & $\cdots$ & $\cdots \cdots$ & $\ldots A$. & C..A \\
\hline 351 & AATTTAAATA & CTTCATTTTT & TGACCCTGCA & GGG & GGAGGTG & ATCCT & ATTT \\
\hline 351 & $\ldots \ldots \ldots$ & .A....CT. & $\ldots \mathrm{T} \ldots \mathrm{T}$ & $\ldots \mathrm{T}$ & $\ldots$ T... & $\ldots A$ & $\cdots \cdots$ \\
\hline 351 & $\cdots \cdots \cdots$ &. $\mathrm{T} \ldots \mathrm{TC}$ & $\ldots C \ldots A$ & N.G & $\ldots$ A... & $\ldots \mathrm{T}$ & $\cdots \cdots$ \\
\hline 401 & АТАТСАACAT & TTATTTTGAT & TCTTTGGACA & $\mathrm{TCC}$ & AGAAGTT & TATAT & -ТTTAA \\
\hline 401 . & $\ldots \ldots \ldots$ & $\ldots \ldots c \ldots$ & C.... T. &. $\mathrm{T} \cdot \mathrm{C}$ & $\mathrm{CN} \ldots \mathrm{A}$ & $\mathrm{T} \ldots \mathrm{T}$ & C.... \\
\hline 401 & $\ldots \ldots \ldots$ & $\ldots$. TN . . & $\mathrm{T} \ldots . . . \mathrm{A} \ldots$ & $. \mathrm{T} . \mathrm{t}$ & $A N \ldots . T$ & $C \ldots \mathrm{C}$ & NNNN . . \\
\hline 451 & TTTTACC-AGG & G-TTTGGGTAT & GA--TTTCTCAT & & ATCATTTC & $\mathrm{CC}$ & GAAAGAGG \\
\hline 452 & $\ldots \ldots \mathrm{C} \cdot \mathrm{G}$ & .А.ТТ..... & $\ldots \mathrm{AT} \ldots \ldots$ & & $\ldots \mathrm{TA} \ldots \mathrm{N}$ & & T.N... \\
\hline 452 & $\ldots \ldots \ldots$ NNT & $\therefore-. C N \ldots \ldots$ & $\ldots \mathrm{TT} \ldots \mathrm{AT} \ldots$ & & T.AC..C. & T. . & G.NA.... \\
\hline 501 & TAAAAA--GGAA & GC--TTTTGG & GAA -ATTTAXGGA & AAXT & $A A T-T$ & TTGCT & ATATTA-GCAA \\
\hline 507 & G.A.A.AG...N & G.CN.T.C. . & .. A. . NNCNGG. & A. & $\ldots-\mathrm{C}$ & TT... C & $\ldots \ldots$ GC $\ldots$ \\
\hline 506 & T.N.N. - . . A & A.CT.N.T. . & . . N. . TTACNN. &. $\mathrm{T}$ & $\ldots$ AN & C...T & $\ldots \ldots$ CG $\ldots$ \\
\hline 551 & TTGG--T-TTAT" & $\mathrm{A}-\mathrm{GGAT}-\mathrm{TTG}$ & STT G--TTTGAGC & CTC $z$ & A-TCATA-? & $\mathrm{AT}-\mathrm{T}$ & TAC-TGTA-GGA \\
\hline 565 & $\ldots$ G.GC..$- N \ldots$ & ANGAA.N... & A. GNTT.T.... & & AA. . A. .- & $\ldots--$ & $-.-\mathrm{NN} . . \mathrm{A}-\mathrm{G}$. \\
\hline 564 & . T.GN.N.C.. & NTNGN. $-\ldots$ &.$- \quad$ CGTN.A. . . & & NT . . . . T & $\ldots \mathrm{CT}$ & A.CTT..NTN.. \\
\hline 601 & A-TA-GATGTGG & $--A T A C C-C G A G C$ & CTA--TTTTA & $\mathrm{A}-\mathrm{CT}$ & $\mathrm{TC}-\mathrm{AG}$ & ТTACTA & TAAT-TATTGC \\
\hline 62 & $.-\ldots-\mathrm{N} . \mathrm{T} \ldots$. A & $--A \ldots T-\ldots G$. & A..T-.T. & $-\ldots$ & $\ldots A G$. & $\ldots \ldots$ & $\ldots$ TA. . . . \\
\hline & . T. GN.C..C. & GNT . . NG . . C. & C..TC.... & & . TA. & $\ldots \ldots$ & $\ldots$ AN . . . . \\
\hline
\end{tabular}

Fig. 3. DNA sequence of CO1 gene of B. germanica, B. Vaga and B. asahinai. Periods respresent identical base; -, gap; and $\mathrm{x}$ indicates the end of the sequence. ${ }^{*} \mathrm{G}$, German cockroach; *F, field cockroach; *A, Asian cockroach.

GENBANK assigned as accession numbers: AF228733 for the Asian cockroach, AF228734 for the German cockroach, and AF228735 for the field cockroach. There were no undetermined bases in German cock- roaches but there were 17 and 59 undetermined bases in field and Asian cockroaches, respectively. Most undetermined bases were between the 400 and $800 \mathrm{bp}$ regions. There was $76 \%$ identity among German, Asian 


\begin{tabular}{|c|c|c|c|c|c|c|c|}
\hline 651 & TGTACCCACT & G-GTATTAAAA & TTTTCAGTTG & ACTAGCTACC & \multicolumn{2}{|c|}{ TAT-ATATG-GA } & ${ }^{\star} \mathrm{G}$ \\
\hline 679 & $\ldots . \mathrm{A} \cdot \mathrm{CA}$ &.$-. A . .$. & $\ldots \mathrm{T} \ldots \mathrm{TG}$ & . . . CAG- & \multicolumn{2}{|c|}{$\ldots \mathrm{T}-\ldots \ldots-\ldots$} & $\star F$ \\
\hline 686 & $\ldots \ldots$. . NT & A.T..... & $\ldots \mathrm{C} \ldots \mathrm{GA}$ & . N. . NTA- . & \multicolumn{2}{|c|}{$\ldots$ NA. . . . NN } & ${ }^{\star} \mathrm{A}$ \\
\hline 701 & TCTCA-ATTAA & C-TTACAGAGC & \multirow{3}{*}{\multicolumn{4}{|c|}{ 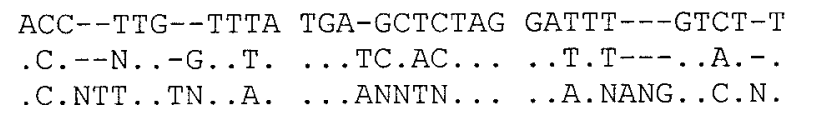 }} & $\star_{G} G$ \\
\hline 30 & $\ldots A A \ldots A$ & . C.T-T... & & & & & ${ }^{\star} \mathrm{F}$ \\
\hline 40 & $\ldots$ NG $\ldots$. G &. T.NAC . . . . & & & & & ${ }^{*} \mathrm{~A}$ \\
\hline 751 & \multicolumn{3}{|l|}{ С--ТTATTTAC-А } & \multicolumn{2}{|c|}{ AGTT----CTTGCT } & AATTCATC-AA & $*^{*} \mathrm{G}$ \\
\hline & $. \mathrm{G}--\mathrm{N} . . \mathrm{TTN} . \mathrm{CT}$ & $\ldots-. c \ldots$ & $\ldots-\ldots \mathrm{GT}$ & \multicolumn{2}{|c|}{$\ldots . T---A \cdot A G C A$} & A. . CATCA.T & ${ }^{\star} \mathrm{E}$ \\
\hline & . GTTA. . NNA . AA & ..G.A... & $\ldots N \ldots N N$ & \multicolumn{2}{|c|}{$\ldots$. TCCNG.GNTA } & G...GNNNC.A & ${ }^{\star} \mathrm{A}$ \\
\hline 801 & TTGATA-TTGT & T-CTTCATGAT & ACATATTATG & TAGTCGCCCA & \multicolumn{2}{|c|}{ TTTCCACTAT } & ${ }^{*} \mathrm{G}$ \\
\hline 39 & . T.... T. &.$-\mathrm{T} . \mathrm{A} \ldots .$. & $\ldots \ldots \ldots$ & ... . . . . & \multirow{2}{*}{\multicolumn{2}{|c|}{$\begin{array}{l}\text { С. . . . . . } \\
\text { Т. С... }\end{array}$}} & $\star E$ \\
\hline 65 & .A...N.G. &. GA.T..... & $\ldots \ldots \ldots$ & $\ldots$. . . . & & & ${ }^{\star} \mathrm{A}$ \\
\hline & GTACTATCTA & TAGGAGCAGT & ATTTGCAATC & ATAGCAGGGT & \multicolumn{2}{|c|}{ TTATTCAATG } & $*^{*} \mathrm{G}$ \\
\hline 1 & $\ldots A T \ldots A$ & $\ldots \ldots$. . . & $\ldots \mathrm{T} \ldots \mathrm{T}$ & $\ldots \ldots$ C. T. & \multicolumn{2}{|c|}{$\ldots \ldots$} & ${ }^{\star} \mathrm{F}$ \\
\hline 918 & $\ldots \mathrm{GT} \ldots \mathrm{T}$ & $\ldots \ldots$ A. & $\ldots$ A.... & $\ldots$. . A. & \multicolumn{2}{|c|}{$\ldots \ldots \ldots$} & ${ }^{\star A} \mathrm{~A}$ \\
\hline 901 & АТАТССАTTA & TTTACTGGTT & ТАТСТTТАAА & TCCAAAGTGA & \multicolumn{2}{|c|}{ TTAAAAATTC } & ${ }^{\star} \mathrm{G}$ \\
\hline 942 & A.... T. . & $\ldots$. A. & $\ldots$ A... & . . . . . & \multicolumn{2}{|c|}{$\ldots \ldots$} & ${ }^{\star} \mathrm{F}$ \\
\hline 969 & G....A... & $\ldots . \mathrm{T} \ldots \mathrm{T}$ & $\ldots \mathrm{T} \ldots \mathrm{A}$ & $\ldots$ A..G. & \multicolumn{2}{|c|}{$\ldots \ldots \ldots$} & $\star A$ \\
\hline 951 & -AATTTTCAAT & TATATTTTTA & GGAGTAAATT & TAACATTTTT & \multicolumn{2}{|c|}{ TCCTCAACAT } & ${ }^{\star} G$ \\
\hline 993 & $-A \ldots A \ldots C$ & A. ......... & . Т..... & $\ldots \ldots \ldots$ & \multicolumn{2}{|c|}{$c \ldots \ldots$} & ${ }^{\star} \mathrm{E}$ \\
\hline 1020 & GN $\ldots$ T. . T & T $\ldots \ldots$ & $\ldots A \ldots G \ldots$ & $\ldots \ldots \ldots$ & \multicolumn{2}{|c|}{$\mathrm{T} \ldots \ldots \ldots$} & ${ }^{\star} \mathrm{A}$ \\
\hline 1001 & TTTCTTGGTT & TAGCCGGAAT & GCCACGACGA & TATTCTGATT & \multicolumn{2}{|c|}{ ATCCTGACGC } & ${ }^{\star} G$ \\
\hline 1044 & .. .A.A. & $\ldots A \ldots$ & A.T.A.G & $\ldots \ldots A \ldots$ & \multicolumn{2}{|c|}{...C.GAT. } & ${ }^{*} \mathrm{~F}$ \\
\hline 1072 & ... . T. T. & $\ldots$. . . . . & $G \ldots A . G . A$ & $\ldots . \mathrm{T} \ldots$ & \multicolumn{2}{|c|}{...N. NNC . } & $* \mathrm{~A}$ \\
\hline 1051 & TTATGCAGCT & TGAAATGTTA & TTTCATCAAT & TGGATCAATA & \multicolumn{2}{|c|}{ ATTTCATTTG } & ${ }^{\star} \mathrm{G}$ \\
\hline 1095 & . T.A.T... & $\ldots \ldots \ldots \mathrm{T}$ & .A. . T.... & $\ldots \ldots \ldots$ & \multicolumn{2}{|c|}{$\ldots$. . . C } & $\star \mathrm{F}$ \\
\hline 1123 & .A.G.A. . & $\ldots \ldots A$ & T..A.... & $\ldots \ldots$ & \multicolumn{2}{|c|}{...... } & ${ }^{\star} \mathrm{A}$ \\
\hline 1101 & TAGCTGTATT & ААТАTTТАТТ & TTTATCATAT & GAGAAAGAAT & \multicolumn{2}{|c|}{ AACTACTAAC } & ${ }^{\star} \mathrm{G}$ \\
\hline 1146 & $\ldots A \ldots$. & т....... & . C...... & $\ldots \ldots \ldots c$ & \multicolumn{2}{|c|}{.T.A. . NN.T } & ${ }^{\star} \mathrm{F}$ \\
\hline 1174 & $\ldots \mathrm{T} \ldots \mathrm{T}$ & A......... & $\ldots$ T. . . . & $\ldots \ldots$ A. & .A.T.TI & & ${ }^{*} \mathrm{~A}$ \\
\hline 1151 & CGACAAGTAT & TATTTCCTAC & TCAAACAAGA & AATTCTATTG & AATGATTI & & $\star^{*} \mathrm{G}$ \\
\hline 1197 & $\ldots \mathrm{C} \ldots \ldots \mathrm{CT}$ & ..Т. . А. & A..AA.T... & $\ldots .-. X$ & & & ${ }^{\star} \mathrm{F}$ \\
\hline 1225 & $\ldots A \ldots \ldots A C$ & $\ldots$... . . & T. . CN.A. . & $\ldots$. $\ldots$ & $\ldots \ldots$ & & ${ }^{*} \mathrm{~A}$ \\
\hline 1201 & ААATATTCCA & CCAGCTGAAC & ATAGTTATGC & TGAATTACCA & ACTATTTC & & $\star^{\star} \mathrm{G}$ \\
\hline 1276 & $\ldots \ldots C \ldots$ & $\cdots \cdots \cdots$ & $\ldots \ldots \ldots-$ & $-. . . \mathrm{C} . \mathrm{X}$ & & & ${ }^{\star} \mathrm{A}$ \\
\hline 1251 & ATTAGATCCG & $\mathrm{TT}$ & & & & & ${ }^{\star} \mathrm{G}$ \\
\hline
\end{tabular}

Fig. 3. Continued

and field cockroaches. Similarly, there were 79, 74, and 69\% identities among Drosophila yakuba Burla and German, field, and Asian cockroaches, respectively (Clary and Wolstenholme 1985). In relation to the $D$. yakuba genome, the position of mtDNA sequences in the German cockroach corresponds to nucleotides 1757 through 3017, for the Asian cockroach it corresponds to nucleotides 1693 through 2988, and for the field cockroach it starts at 1735 and ends at 2941 (Clary and Wolstenholme 1985). Further, the dentogram (Fig. 4), using sequence data from German, Asian, and field cockroaches, and the cricket Gryllus pennsylvanicus Burmeister, showed that the German cockroach is more closely related to the Asian cockroach than the field cockroach. The sequence data of the cricket (accession no. GPU88332) were used as an outgroup, and the sequence data of $B$. germanica are available as accession no. S72627. 


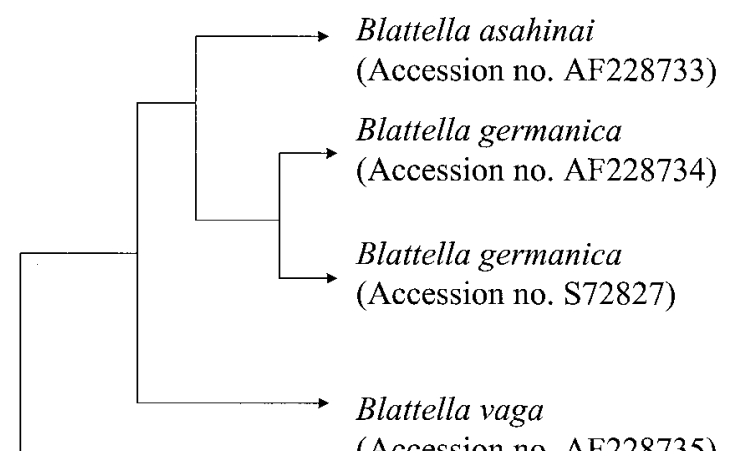

(Accession no. AF228735)

Gryllus pennsylvanicus

(Accession no. GPU88332)

\section{Substitutions per 100 residues}

Fig. 4. Growtree dentogram from the COl gene sequence of German, Asian, and field cockroach, and a cricket (outgroup) compiled by pileup program using the unweighted pair-group method with arithmetic average method.

\section{Discussion}

We demonstrated that PCR-RFLP could be used to differentiate three closely related Blattella spp. AluI digested amplicons (517 bp CO1 and $1275 \mathrm{bp} \mathrm{CO1/}$ TL2) were useful in discriminating German, Asian and field cockroaches. However, the usefulness of $\mathrm{CO} 1$ digested amplicons ( $517 \mathrm{bp}$ ) is limited because of the intraspecific polymorphism and band separation by few base pairs. Scott et al. (1993) stated that the PCR fragments diagnostic for species must differ by at least 50 nucleotides for unambiguous discrimination. In contrast to the $517 \mathrm{bp}$ amplicons, the $1275 \mathrm{bp} \mathrm{CO1/}$ TL2 amplicons that was digested by AluI showed consistent banding patterns in all gels. Although intraspecific polymorphism was observed in the $1275 \mathrm{bp}$ amplicons of German cockroaches, the banding pattern of the German cockroach was clearly distinct from that of the Asian and field cockroach. There was no intraspecific polymorphism in the $1275 \mathrm{bp}$ amplicons of the Asian and field cockroach. Furthermore, the $540 \mathrm{bp}$ fragment is found only in the Asian cockroach, whereas the $403 \mathrm{bp}$ is found in the field cockroach. Roehrdanz et al. (1994) and Szalanski and Powers (1996) also reported similar results. In the study by Szalanski and Powers (1996), intraspecific polymorphism was observed for the northern corn rootworm $(n=15)$ but the bands were discrete enough for differentiation of three corn rootworm species. Based on our study, species discrimination of the German, Asian, and field cockroaches can be performed by amplifying the mtDNA with CI-J-1751 and TL-2-N3014 primer combinations and digesting the amplicons with the restriction enzyme AluI. Furthermore, current technology (PCR and DNA sequencer) has led to rapid and efficient sequencing procedures (Hoy 1994,
Martinez-Gonzales and Hegardt 1994) where sequences are determined directly from the PCR products (Kambhampati 1995, 1996). We found 99.2\% identity between the $\mathrm{CO} 1$ gene sequences of German cockroaches that were sequenced directly from the PCR product and the sequence obtained in another study where cloning procedures were used (Martinez-Gonzales and Hegardt 1994). Variation between the two sequence procedures was caused by transition at 10 locations $(295,367,397,451,1107,1251,1327$, 1415,1418 , and 1488) and insertion at two locations (between 738 and 739, and 961 and 962).

We also observed differences in total length of the amplicons (in both $517 \mathrm{bp}$ and $1275 \mathrm{bp}$ amplicons) between the undigested and digested fragments. Disparity in the total length of the fragment size ranging from -426 to +980 bp between the undigested and digested fragments has also been reported by other researchers (Roehrdanz et al. 1994, Roehrdanz et al. 1997, Taylor and Szalanski 1999, Taylor et al. 1997). Presence of the double bands could result in the estimated length of the digested amplicon being lower than the undigested amplicons (Roehrdanz 1994, Taylor and Szalanski 1999, Taylor et al. 1997). In our study, this was observed with digested amplicons (1275 bp) of B. germanica-A and B. asahinai. However, total length of the digested fragments being higher than the undigested amplicons could have resulted from both partial digestion and the sensitivity of the silver staining method (Taylor et al. 1997). Because silver staining is three times more sensitive than the ethidium bromide staining, it is possible to detect bands of low intensity with the silver staining method (Merril 1990) in comparison to with ethidium bromide method. In our study, this was observed with $517 \mathrm{bp}$ amplicon of B. asahinai-A, $1275 \mathrm{bp}$ amplicon of B. germanica-B, and $1275 \mathrm{bp}$ amplicon of B. vaga (Taylor et al. 1997). Even with increased enzyme concentration, we observed similar banding patterns of digested fragments by the silver staining method. Moreover, small differences in the total length of the amplicons between undigested and digested fragment might be a result of the secondary structure of the double stranded DNA, which affects migration of DNA in PAGE (Taylor et al. 1996).

In addition to morphologically based taxonomy, the application of allozyme electrophoresis, PCR-RFLP, RAPD-PCR, and SSCP are molecular techniques that can be used for species identification as well as evolutionary or phylogenetic studies (Hoy 1994, Black and DuTeau 1997). Success of the PCR-RFLP technique is based on the presence of restriction sites in the amplified region of either genomic DNA or mtDNA using specific restriction enzymes (West et al. 1997). Publication of the primer list for amplifying insect mtDNA (Simon et al. 1994) has led to the efficient and reliable use of PCR-RFLP for species identification using mtDNA. Most of the universal primer combinations used here were successful in amplifying a portion of the mtDNA. In addition to universal primers, PCR-RFLP can also be used for discriminating species with primers that amplify the internal transcribed spacers (ITS) and intergenic 
spacers (IGS) of ribosomal DNA (Scott et al. 1993, Beebe and Saul 1995, and West et al. 1997). But, RFLP analysis of ITS amplicons of three Blattella spp. did not result in positive species discrimination patterns in our study. Single-strand conformation polymorphism (SSCP) is another technique that can be used for species discrimination but it requires silver staining for visualizations of the bands. Although silver staining is elaborate and more expensive than ethidium bromide staining, SSCP is very sensitive to single base pair changes. SSCP can be more efficient and less time consuming than PCR-RFLP or RAPD-PCR but the sensitivity of the SSCP analysis decreases as the basepair number increases (Hiss et al. 1994. Black and DuTeau 1997). West et al. (1997) used SSCP analysis for species discrimination but observed identical patterns and attributed the failure to detect differences to the size of amplicons $(1 \mathrm{~kb})$. We suggest that for amplicons with $450 \mathrm{bp}$ or more, PCR-RFLP may be the most efficient procedure for species identification of cockroaches using universal primers.

\section{Acknowledgments}

We thank Arthur G. Appel (Auburn University, Auburn, AL) for providing Asian and field cockroaches and Phillip G. Koehler (University of Florida, Gainesville, FL) for providing additional Asian cockroaches. We also thank Marcia D. Elliott (Center for Biotechnology, University of Nebraska, Lincoln, NE) for invaluable assistance with DNA sequencing. We are grateful to Steve Skoda and Mike Scharf for critical reviews of the manuscript. This is published as paper No.12893, Journal Series of the Nebraska Agricultural Division and contribution No. 1061 of the Department of Entomology, Institute of Agricultural and Natural Resources, University of Nebraska, Lincoln.

\section{References Cited}

Appel, A. G. 1995. Blattella and related species, pp. 1-19. In M. K. Rust, J. M. Owens, and D. A. Reierson [eds.], Understanding and controlling the German cockroach, Oxford University Press, New York.

Atkinson, T. H., P. G. Koehler, and R. S. Patterson. 1991. Catalog and atlas of the cockroaches (Dictyoptera) of the North America north of Mexico. Entomol. Soc. Am. Misc. Publ. 78: 1-86.

Beebe, N. W., and A. Saul. 1995. Discrimination of all members of the Anopheles punctulatus complex by polymerase chain reaction-restriction length polymorphism analysis. Am. J. Trop. Med. Hyg. 53: 478-481.

Benson, E. P., and P. A. Zungoli. 1997. Cockroaches, pp. 123-204. In S. A. Hedge and D. Moreland [eds.], Handbook of pest control: The behavior, life history and control of household pests, 8th ed. Mallis Handbook and Technical Training Company. Pest Control Technology, Cleveland, $\mathrm{OH}$.

Black IV, W. C., and N. M. DuTeau. 1997. RAPD-PCR and SSCP analysis for insect population genetics studies, pp. 361-373. In J. M. Crampton, C. B. Beard, and C. Louis [eds.], The molecular biology of insect disease vectors: a method manual, Chapman \& Hall, New York.

Blomquist, G. J., D. R. Nelson, and M. de Renobales. 1987. Chemistry, biochemistry, and physiology of insect cuticular lipids. Arch. Insect. Biochem. Physiol. 6: 227-265.
Brenner, R. J., R. S. Patterson, and P. G. Koehler. 1988. Ecology, behavior, and distribution of Blattella asahinai (Orthoptera: Blattellidae) in central Florida. Ann. Entomol. Soc. Am. 81: 432-436.

Broughton, R. E. 1995. Mitochondrial DNA variation within and among species of termites in the genus Zootermopsis (Isoptera: Termopsidae). Ann. Entomol. Soc. Am. 88: $120-128$.

Carlson, D. A., and R. J. Brenner. 1988. Hydrocarbon-based discrimination of three North American Blattella cockroach species (Orthoptera: Blattellidae) using gas chromatography. Ann. Entomol. Soc. Am. 81: 711-723.

Clary, D. O., and D. R. Wolstenholme. 1985. The mitochondrial DNA molecule of Drosophila yakuba: nucleotide sequence, gene organization, and genetic code. J. Mol. Evol. 22: 252-271.

Flock, R. A. 1941. The field roach Blattella vaga. J. Econ. Entomol. 34: 121.

Golden, K. L., L. J. Meinke, and D. W. Stanley-Samuelson. 1992. Cuticular hydrocarbon discrimination of $\mathrm{Di}$ abrotica (Coleoptera: Chrysomelidae) sibling species. Ann. Entomol. Soc. Am. 85: 561-570.

Hadley, N. F. 1977. Epicuticular lipids of the desert tenebrionid beetle, Eleodes armata: seasonal and acclimatory effects on composition. Insect. Biochem. 7: 277-283.

Hall, R. 1987. Trouble on wing. Pest Control 55: 28-32.

Hiss, R. H., D. E. Norris, C. H. Dietrich, R. F. Whitcomb, D.F. West, C.F. Bosio, S. Kambhampati, J. Piesman, M.F. Antolin, and W. C. Black IV. 1994. Molecular taxonomy using single-strand conformation polymorphism (SSCP) analysis of mitochondrial ribosomal DNA genes. Insect Mol. Biol. 3: 171-182.

Hoy, M. A. 1994. Insect molecular genetics: an introduction to principles and applications. Academic, New York.

Kambhampati, S. 1995. A phylogeny of cockroaches and related insects based on DNA sequence of mitochondrial ribosomal RNA genes. Proc. Natl. Acad. Sci. U.S.A. 92: 2017-2020.

Kambhampati, S. 1996. Phylogenetic relationship among cockroach families inferred from mitochondrial $12 \mathrm{~S}$ rRNA gene sequence. Syst. Entomol. 21: 89-98.

Kirby, L. T. 1990. DNA fingerprinting: an introduction. Stockton, New York.

Lawless, L. S. 1999. Morphological comparisons between two species of Blattella (Dictyoptera: Blatellidae). Ann. Entomol. Soc. Am. 92: 139-143.

Maniatis, T., E. F. Fritsch, and J. Sambrook. 1982. Molecular cloning; a laboratory manual. Cold Spring Harbor Laboratory, Cold Spring Harbor, NY.

Martinez-Gonzales, J., and F. G. Hegardt. 1994. Cytochrome $c$ oxidase subunit 1 from the cockroach Blattella germanica: cloning, developmental pattern and tissue expression. Insect Biochem. Mol. Biol. 24: 619-626.

Merril, C. R. 1990. Silver staining of proteins and DNA. Nature (Lond.) 343: 779780.

Moritz, C., T. E. Dowling, and W. M. Brown. 1987. Evolution of animal mitochondrial DNA: relevance for population biology and systematics. Annu. Rev. Ecol. Syst. 18: 269-272.

Navajas, M., J. Lagnel, J. Gutierrez, and P. Boursot. 1998. Species-wide homogeneity of nuclear ribosomal ITS2 sequences in the spider mite Tetranychus urticae contrasts with extensive mitochondrial $\mathrm{CO}$ polymorphism. Heredity $742-752$.

Roehrdanz, R. L. 1997. Identification of tobacco budworm and corn earworm (Lepidoptera: Noctuidae) during early developmental stages by polymerase chain reaction and restriction fragment length polymorphism. Ann. Entomol. Soc. Am. 90: 329-332. 
Roehrdanz, R. L, J. D. Lopez, J. Loera, and D. E. Hendricks. 1994. Limited mitochondrial polymorphism in North American populations of Heliothis virescens (Lepidoptera: Noctuidae). Ann. Entomol. Soc. Am. 87: 856-866.

Ross, M. H. 1992. Genetic studies of a morphological character that separates two species of Blattella (Dictyoptera: Blatellidae). J. Entomol. Sci. 27: 251-256.

Ross, M. H., and D. E. Mullins. 1988. Nymphal and oothecal comparisons of Blattella asahinai and Blattella germanica (Dictyoptera: Blattellidae). J. Econ. Entomol. 81: 1645-1646.

Roth, L. M. 1986. Blattella asahinai introduced into Florida (Blattaria: Blattellidae). Psyche 93: 371-374.

Scott, J. A., W. G. Brogdon, and F. H. Collins. 1993. Identification of single specimens of the Anopheles gambiae complex by the polymerase chain reaction. Am. J. Trop. Hyg. 49: 520-529.

Simon, C., F. Frati, A. Beckenbach, B. Crespi, H. Liu, and P. Flook. 1994. Evolution, weighting, and phylogenetic utility of mitochondrial gene sequences and a compilation of conserved polymerase chain reaction primers. Ann. Entomol. Soc. Am. 87: 651-701.

Szalanski, A. L., and T. O. Powers. 1996. Molecular diagnostics of three Diabrotica (Coleoptera: Chrysomelidae) pest species. J. Kans. Entomol. Soc. 69: 260-266.
Taylor, D. B., and A. L. Szalanski. 1999. Identification of Muscidifurax spp. by polymerase chain reaction-restriction fragment length polymorphism. Biol. Control 15: 270-273.

Taylor, D. B., A. L. Szalanski, and R. D. Peterson II. 1996. Identification of screwworm species by polymerase chain reaction-restriction fragment length polymorphism. Med. Vet. Entomol. 10: 63-70.

Taylor, D. B., R. D. Peterson II, A. L. Szalanski, and J. J. Petersen. 1997. Mitochondrial DNA variation among Muscidifurax spp. (Hymenoptera: Pteromalidae), pupal parasitoids of filth flies (Diptera). Ann. Entomol. Soc. Am. 90: 814-824.

Toolson, E. C., T. A. Markow, L. L. Jackson, and R. W. Howard. 1990. Epicuticular hydrocarbon composition of wild and laboratory-reared Drosophila mojavensis Patterson \& Crow (Diptera: Drosophilidae). Ann. Entomol. Soc. Am 83: 1165-1176.

West, D. F., T. Payette, T. Mundy, and W. C. Black IV. 1997. Regional molecular genetic key of thirteen snow pool Aedes species (Diptera: Culicidae) in Northern Colorado. J. Med. Entomol. 34: 404-410.

Received for publication 2 February 2000; accepted 23 June 2000 . 